\title{
Impact of rapid sea-ice reduction in the Arctic Ocean on the rate of ocean acidification
}

\author{
A. Yamamoto ${ }^{1,2, *}$, M. Kawamiya ${ }^{1}$, A. Ishida ${ }^{1,3}$, Y. Yamanaka ${ }^{1,2}$, and S. Watanabe ${ }^{1}$ \\ ${ }^{1}$ Japan Agency for Marine-Earth Science and Technology, Yokohama, Japan \\ ${ }^{2}$ Graduate school of Environmental Science, Hokkaido University, Sapporo, Japan \\ ${ }^{3}$ Department of Social Environment, Fuji Tokoha University, Fuji, Japan \\ * now at: Atmosphere and Ocean Research Institute, University of Tokyo, Kashiwa, Chiba 277-8568, Japan
}

Correspondence to: A. Yamamoto (akitomo@ees.hokudai.ac.jp)

Received: 7 October 2011 - Published in Biogeosciences Discuss.: 28 October 2011

Revised: 24 May 2012 - Accepted: 1 June 2012 - Published: 29 June 2012

\begin{abstract}
The largest $\mathrm{pH}$ decline and widespread undersaturation with respect to aragonite in this century due to uptake of anthropogenic carbon dioxide in the Arctic Ocean have been projected. The reductions in $\mathrm{pH}$ and aragonite saturation state in the Arctic Ocean have been caused by the melting of sea ice as well as by an increase in the concentration of atmospheric carbon dioxide. Therefore, future projections of $\mathrm{pH}$ and aragonite saturation in the Arctic Ocean will be affected by how rapidly the reduction in sea ice occurs. The observed recent Arctic sea-ice loss has been more rapid than projected by many of the climate models that contributed to the Intergovernmental Panel on Climate Change Fourth Assessment Report. In this study, the impact of sea-ice reduction rate on projected $\mathrm{pH}$ and aragonite saturation state in the Arctic surface waters was investigated. Reductions in $\mathrm{pH}$ and aragonite saturation were calculated from the outputs of two versions of an Earth system model with different sea-ice reduction rates under similar $\mathrm{CO}_{2}$ emission scenarios. The newer model version projects that Arctic summer ice-free condition will be achieved by the year 2040, and the older version predicts ice-free condition by 2090 . The Arctic surface water was projected to be undersaturated with respect to aragonite in the annual mean when atmospheric $\mathrm{CO}_{2}$ concentration reaches 513 (606) ppm in year 2046 (2056) in new (old) version. At an atmospheric $\mathrm{CO}_{2}$ concentration of $520 \mathrm{ppm}$, the maximum differences in $\mathrm{pH}$ and aragonite saturation state between the two versions were 0.1 and 0.21 respectively. The analysis showed that the decreases in $\mathrm{pH}$ and aragonite saturation state due to rapid sea-ice reduction were caused by increases in both $\mathrm{CO}_{2}$ uptake and freshwater in-
\end{abstract}

put. Thus, the reductions in $\mathrm{pH}$ and aragonite saturation state in the Arctic surface waters are significantly affected by the difference in future projections for sea-ice reduction rate. Our results suggest that the future reductions in $\mathrm{pH}$ and aragonite saturation state could be significantly faster than previously projected if the sea-ice reduction in the Arctic Ocean keeps its present pace.

\section{Introduction}

The emission of large amounts of anthropogenic carbon dioxide $\left(\mathrm{CO}_{2}\right)$ has increased global atmospheric $\mathrm{CO}_{2}$ concentration from a preindustrial value of $280 \mathrm{ppm}$ to $391 \mathrm{ppm}$ in 2011, and is contributing to global warming (IPCC, 2007). Rising atmospheric $\mathrm{CO}_{2}$ and global warming are tempered by oceanic uptake, which absorbs nearly one-third of anthropogenic $\mathrm{CO}_{2}$ released to the atmosphere (Sabine et al., 2004). However, anthropogenic $\mathrm{CO}_{2}$ penetration into the ocean increases hydrogen ion concentration and causes a reduction in $\mathrm{pH}$, a process known as ocean acidification. The average surface ocean $\mathrm{pH}$ has already decreased by about 0.1 (from a pH of 8.2 to 8.1) since the 1700 s due to absorption of anthropogenic $\mathrm{CO}_{2}$ (Royal Society, 2005). A previous modeling study suggested that an additional decrease of 0.3 0.4 will occur when atmospheric $\mathrm{CO}_{2}$ concentration reaches $800 \mathrm{ppm}$ by the year 2100 (Orr et al., 2005). This reduction in ocean $\mathrm{pH}$ has some direct effects on many marine organisms (Seibel and Walsh, 2001; Ishimatsu et al., 2005). 
Carbonate ion $\left(\mathrm{CO}_{3}^{2-}\right)$ concentrations and the saturation state $(\Omega)$ of calcium carbonate $\left(\mathrm{CaCO}_{3}\right)$ minerals such as calcite and aragonite also are decreased due to dissolution of $\mathrm{CO}_{2}$ into the ocean. Carbonate ions are required by marine calcifying organisms such as plankton, shellfish, coral, and fish to produce $\mathrm{CaCO}_{3}$ shells and skeletons. Shell and skeleton formation generally occurs in supersaturated seawater $(\Omega>1.0)$, and dissolution occurs in undersaturated seawater $(\Omega<1.0)$. Thus, $\mathrm{CaCO}_{3}$ saturation state is a key variable for assessing the biological impacts of ocean acidification. In surface waters, $\Omega$ is lower in cold, high-latitude oceans than in tropical and temperate oceans because of increased $\mathrm{CO}_{2}$ solubility, the sensitivity of acid-base dissociation coefficients at cold temperatures, and ocean mixing patterns. Although surface waters in high-latitude oceans today are generally supersaturated with respect to aragonite (aragonite is more soluble than calcite), recent studies have reported undersaturated seawater in the Canada Basin of the Arctic Ocean (Yamamoto-Kawai et al., 2009; Bates et al., 2009). From the modeling projections, small regions of surface water in the Arctic Ocean may already be undersaturated with respect to aragonite (Gangst $\varnothing$ et al., 2008) or will become undersaturated within a decade under the A2 Scenario of the Special Report on Emissions Scenarios (SRESA2) (Steinacher et al., 2009; Frölicher and Joos, 2010). After that, undersaturation will begin to occur in the Southern Ocean by 2030 (McNeil and Matear, 2008), and the North Pacific by 2100 under IS92a scenario, which is similar to the SRES-A2 scenario (Orr et al., 2005). In addition to surface waters, the coastal waters of western North America are undersaturated seasonally as upwelling lifts up deep water of the North Pacific Ocean, in which aragonite saturation horizon is shallowest in the global ocean (Feely et al., 2008). The oceanic uptake of anthropogenic $\mathrm{CO}_{2}$ also increases the area of undersaturated coastal water. Therefore, understanding that the aragonite saturation state $\left(\Omega_{\text {arag }}\right)$ decreases in the Arctic Ocean, which is projected to be one of the first oceans to experience undersaturation, it is important for avoiding the risk of large changes in marine ecosystems.

Future surface $\mathrm{pH}$ and $\Omega_{\text {arag }}$ value closely track changes in atmospheric $\mathrm{CO}_{2}$. The equilibrium of dissolved inorganic carbon follows well-established chemistry in seawater, and the effect of climate change is relatively small (Orr et al., 2005; Zeebe et al., 2008). Steinacher et al. (2009) suggested that sea-ice reduction in the Arctic Ocean reduces $\mathrm{pH}$ and $\Omega_{\text {arag }}$ by comparing the simulations with and without warming. This is because the increases in $\mathrm{CO}_{2}$ uptake by air-sea gas exchange due to the disappearance of seaice cover and freshwater input from increased precipitation, river runoff, and ice melt decrease $\mathrm{pH}$ and $\Omega_{\text {arag }}$ in the Arctic Ocean. Thus, projections of $\mathrm{pH}$ and $\Omega_{\text {arag }}$ values for the Arctic Ocean are affected by sea-ice reduction due to climate change.

In most model projections adopted in the Intergovernmental Panel on Climate Change Fourth Assessment Report
(IPCC AR4), summer sea ice in the Arctic Ocean will still remain until 2100, and only a few models predict sea ice- free Arctic in September by the end of the 21st century. However the observed recent Arctic sea-ice loss has been more rapid than projected in these models adopted for IPCC AR4 (Stroeve et al., 2007). Wang and Overland (2009) predicted sea ice-free Arctic in September by the year 2037, by correcting biases in six IPCC AR4 models based on the satelliteobserved sea- ice extent. Previous studies, such as Steinacher et al. (2009), focused on a single model with a relatively low sea-ice reduction rate. If a summer sea-ice-free condition is reached within $30 \mathrm{yr}$, the rate of ocean acidification in the Arctic Ocean would be faster than previously projected.

In this study, the relation between rates of sea-ice reduction and surface ocean acidification is investigated by comparing two versions of an Earth system model (ESM). One of these versions projects summer ice-free condition by the year 2040 under the Representative Concentration Pathways 8.5 (RCP8.5) scenario (Moss et al., 2010), while the other version by 2090 under the SRES A2 scenario. First, pH and $\Omega_{\text {arag }}$ projected by both versions are compared with the observed value, and model biases are calculated. Then, we investigate the difference in physical and carbon-system variables between two versions of ESM due to rapid sea-ice reduction. We compare the projections of surface $\mathrm{pH}$ and $\Omega_{\mathrm{arag}}$ between two versions after removing model biases. The main purpose of the present study is to discuss the mechanisms promoting ocean acidification due to rapid sea-ice reduction. Results from auxiliary analysis are also introduced to better understand specific processes of ocean acidification; we analyze the difference in behavior between $\mathrm{pH}$ and $\Omega_{\text {arag }}$ under high atmospheric $\mathrm{CO}_{2}$ concentrations and the change of the seasonal cycle due to sea-ice reduction.

\section{Methods}

\subsection{Models and experiments}

The two versions of ESM used in this study were MIROCESM (Watanabe et al., 2011) and its prototype version (Kawamiya et al., 2005). Prototype version was adopted for the Coupled Climate-Carbon Cycle Model Intercomparison Project (C ${ }^{4} \mathrm{MIP}$ ) with the name "FRCGC" (Friedlingstein et al., 2006); it made a significant contribution to IPCC AR4. MIROC-ESM was developed for Coupled Model Intercomparison Project phase-5 (CMIP5), which is expected to contribute to IPCC AR5. Hereafter, these two versions are designated the "CMIP5" and "C ${ }^{4}$ MIP", respectively. The components coupled in both versions are shown in Table 1. Two versions are based on the physical climate system model MIROC, in which atmosphere, ocean, sea ice, land surface components, and river routine are coupled by a flux coupler without flux adjustments (K-1 Model Developers, 2004). The atmospheric model used in "C ${ }^{4}$ MIP" ("CMIP5") has a 
(a)

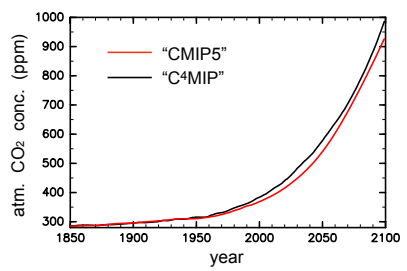

(c)

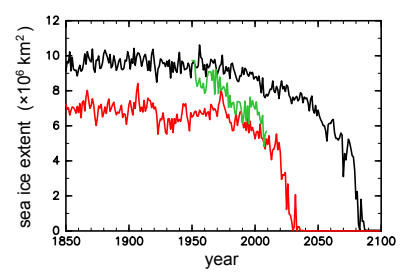

(b)

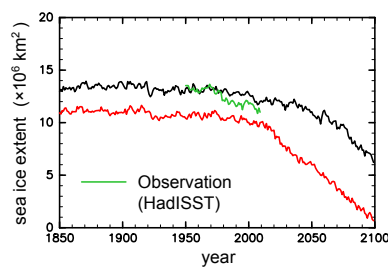

(d)

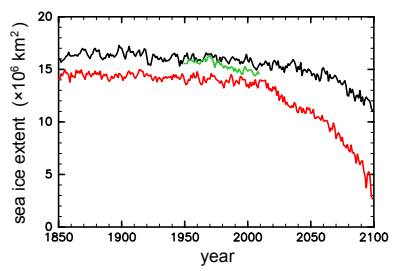

Fig. 1. Projected global annual mean atmospheric $\mathrm{CO}_{2}$ concentrations (a), annual mean (b), September mean (c), and March mean (d), sea-ice extent in the Arctic Ocean for " $\mathrm{C}^{4} \mathrm{MIP}$ " (black) and "CMIP5" (red) model versions. The green line is based on HadISST analysis. The sea-ice extent is defined as the total area with a sea-ice concentration greater than $15 \%$. These results are not drift corrected.

horizontal resolution of T42, approximately equivalent to a $2.8^{\circ}$ grid size with 20 (80) vertical levels. The ocean and sea-ice model in both versions is the COCO 3.4. The ocean model has a zonal resolution of $1.4^{\circ}$ and a spatially varying meridional resolution that is about $0.56^{\circ}$ at latitudes lower than $8^{\circ}$ and $1.4^{\circ}$ at latitudes higher than $65^{\circ}$ and changes smoothly in between. The vertical coordinate is a hybrid of sigma-z, resolving 44 levels in total: 8 sigma-layers near the surface, $35 \mathrm{z}$-layers beneath, plus one boundary layer. The sea ice is based on a two-category thickness representation, zero-layer thermodynamics (Semtner, 1976), and dynamics using elastic-viscous-plastic rheology (Hunke and Dukowicz, 1997).

On the basis of MIROC, "CMIP5" incorporates the terrestrial ecosystem model SEIB-DGVM (Sato et al., 2007) dealing with dynamic vegetation, and " $\mathrm{C}^{4} \mathrm{MIP}$ " has SimCYCLE (Ito and Oikawa, 2002), which is a terrestrial carbon model with fixed vegetation. Ocean biological and chemical processes in both versions are represented by a fourcompartment model consisting of nutrients, phytoplankton, zooplankton, and detritus (Oschlies and Garcon, 1999; Oschlies, 2001). This NPZD type ocean ecosystem model is enough to resolve the seasonal excursion of oceanic biological activities on a basin scale (Kawamiya et al., 2000). In addition, a series of inorganic carbon reactions has been introduced following recommendations by the Ocean Carbon-cycle Model Intercomparison Project (OCMIP) (Orr et al., 1999).

We used model outputs of "C ${ }^{4}$ MIP" conducted by Yoshikawa et al. (2008) under SRES A2 (Fig. 1a). The spin-

up run for the carbon cycle component in "C ${ }^{4} \mathrm{MIP}$ " was conducted by running the integrated model for $250 \mathrm{yr}$, starting with the initial conditions based on climatological data sets (Specifically, the results of MIROC spin-up conducted by the K-1 Model Developers (2004) were provided for the physical climate system, the results of Sim-CYCLE offline spin-up were provided for the terrestrial carbon cycle, the data of the Global Ocean Data Analysis Project were provided for the marine $\mathrm{CO}_{2}$ system, and the data of the World Ocean Atlas 1998 were provided for the marine ecosystem model.). As a result, the globally integrated $\mathrm{CO}_{2}$ fluxes between the atmosphere and land/ocean reach a quasi-steady state. After the spin-up, historical simulation was performed for the years from 1850 to 1999 using anthropogenic fossil fuel emission data (Marland et al., 2005). $\mathrm{CO}_{2}$ emission was given based on SRES A2 for 2000-2100.

Similarly, "CMIP5" was spun-up for $280 \mathrm{yr}$ with the preindustrial initial condition from offline spin-up of SEIBDGVM and ocean model including ocean carbon cycle (see Watanabe et al., 2011 for details). The historical simulation using a set of external forcings recommended by CMIP5 throughout 1850-2005 was conducted by Watanabe et al. (2011). The RCP8.5 was given for 2006-2100 in "CMIP5". It may be noteworthy that atmospheric $\mathrm{CO}_{2}$ concentration in " ${ }^{4} \mathrm{MIP}$ " was predicted by the carbon-cycle components with the given $\mathrm{CO}_{2}$ emissions, while it was provided as input data for "CMIP5" following the CMIP5 protocol. There was little difference in atmospheric $\mathrm{CO}_{2}$ concentration between two versions, with a maximum difference of 60 ppm in 2100.

In the control run of "C $\mathrm{C}^{4} \mathrm{MIP}$ " ("CMIP5"), the global net atmosphere-ocean $\mathrm{CO}_{2}$ exchange is $-0.2(-0.05) \mathrm{PgC} \mathrm{yr}^{-1}$ while atmosphere-land $\mathrm{CO}_{2}$ exchange $+0.1(+0.03) \mathrm{PgC} \mathrm{yr}^{-1}$ (Fig. 2). These drifts may be caused by short spin-up time. Since ocean drifts of -0.2 and $-0.05 \mathrm{PgC} \mathrm{yr}^{-1}$ are larger than the OCMIP 2 threshold of $0.01 \mathrm{PgC} \mathrm{yr}^{-1}$ (Orr, 2002), we discuss the effect of ocean drift on projected $\mathrm{pH}$ and $\Omega_{\text {arag }}$ in Sect. 4.4. Although ocean drifts in control run are relatively large, the drifts of sea surface temperature and sea-ice extent are sufficiently small.

\subsection{Carbonate calculation and target area}

Model outputs of seawater temperature $(T)$, salinity $(S)$, alkalinity (Alk), and dissolved inorganic carbon (DIC), and observational values of phosphate $\left(\mathrm{PO}_{4}^{3-}\right)$ and silicate $\left(\mathrm{Si}(\mathrm{OH})_{4}\right)$ were used for deriving diagnosis on carbonate chemistry. These two observational datasets were used from the World Ocean Atlas 2005 (Locarnini et al., 2006), because these two parameters are not calculated in our ESM. However, the influence of treatments such as $\mathrm{PO}_{4}^{3-}$ and $\mathrm{Si}(\mathrm{OH})_{4}$ on $\mathrm{pH}$ and $\Omega_{\text {arag }}$ are very small. To compute $\mathrm{pH}$ and carbonate ion values, the parameters and the chemistry routine from the OCMIP-3 project (http://ocmip5.ipsl.jussieu. fr/OCMIP) were used. The calcium ion concentration is 
Table 1. Model components between both versions.

\begin{tabular}{llllll}
\hline & Atmosphere & $\begin{array}{l}\text { Ocean and } \\
\text { sea ice }\end{array}$ & $\begin{array}{l}\text { Ocean } \\
\text { Ecosystem }\end{array}$ & Land & $\begin{array}{l}\text { Land } \\
\text { Ecosystem }\end{array}$ \\
\hline C $^{4}$ MIP & AGCM (L20) & COCO 3.4 & NPZD-type & MATSIRO & SIM-CYCLE \\
CMIP5 & AGCM (L80) & Same as C ${ }^{4}$ MIP & Same as C ${ }^{4}$ MIP & Same as C ${ }^{4}$ MIP & SEIB-DGVM \\
\hline
\end{tabular}
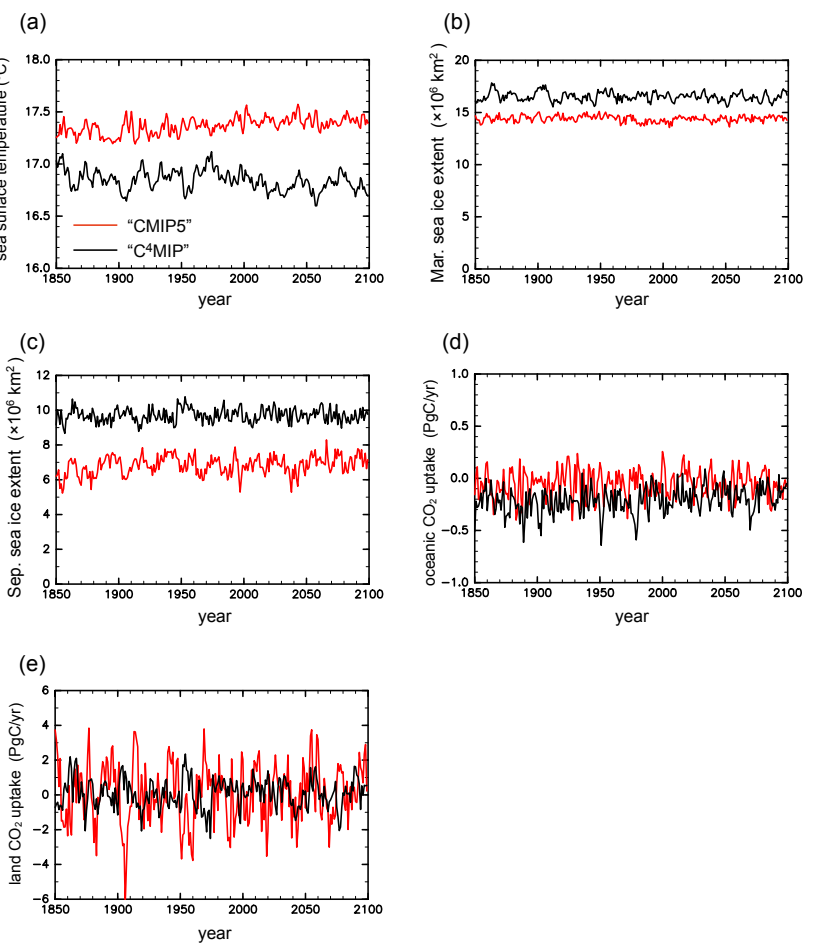

Fig. 2. Simulated global (a) sea surface temperature, (b) September and (c) March mean sea-ice extent in the Arctic Ocean for " ${ }^{4} \mathrm{MIP}$ " (black) and "CMIP5" (red) in the control simulations. Global annual mean (d) oceanic and (e) land $\mathrm{CO}_{2}$ uptake.

assumed to be proportional to the salinity (Riley and Tongudai, 1967). Surface $\mathrm{CaCO}_{3}$ solubility product was calculated based on Mucci (1983) and the pressure effect based on Millero (1995). For comparison with projected $\mathrm{pH}$ and $\Omega_{\text {arag }}$, observed values were calculated using OCMIP chemistry routine and the data of $T, S$, Alk, DIC, $\mathrm{PO}_{4}^{3-}$, and $\mathrm{Si}(\mathrm{OH})_{4}$ from the Arctic Ocean Expedition 1991 (ODEN91, cruise 77DN1991072), Arctic Ocean Section 1994 (AOS94, cruise 18SN19940726), and the Arctic Climate System Study 1996 (ARCSYS-96, cruise 06AQ19960712). These data are available from the CARINA database (http://cdiac. ornl.gov/oceans/CARINA/Carina_table.html). The $\mathrm{pH}$ and $\Omega_{\text {arag }}$ values in more recent periods were calculated using observed $T, S$, Alk and DIC in the Joint Ocean Ice Study (JOIS) 2008 (Yamamoto-Kawai et al., 2009) and August $\mathrm{PO}_{4}^{3-}$ and $\mathrm{Si}(\mathrm{OH})_{4}$ concentrations of the World Ocean Atlas 2005. The target area of Arctic Ocean defined here is north of $65^{\circ} \mathrm{N}$, except for the Labrador Sea and Greenland, Iceland, Norwegian, and Barents Seas $\left(<80^{\circ} \mathrm{N}\right.$ and $35^{\circ} \mathrm{W}-$ $60^{\circ} \mathrm{E}$ ) where sea ice does not exist in "C ${ }^{4} \mathrm{MIP}$ " or "CMIP5". Those areas were excluded from the analysis, because the present study focuses on the effect of sea-ice reduction on ocean acidification.

\section{Results}

\subsection{Comparison of $\mathrm{pH}$ and aragonite saturation between model and observation}

The $\Omega_{\text {arag }}$ and $\mathrm{pH}$ in the top $200 \mathrm{~m}$ of the Arctic Ocean predicted in the two model versions were compared with observed values calculated from ODEN-91, AOS-94, ARCSYS-96, and JOIS 08 for the same place and time (Fig. 2). A comparison of the two model versions with the 1990's[CE]This is indeed possessive. observations of ODEN-91, AOS-94, and ARCSYS-96 reveals that " $\mathrm{C}^{4} \mathrm{MIP}$ " ("CMIP5") tends to underestimate $\Omega_{\text {arag }}$ by $0.3(0.24)$ at the surface. In both versions, most of the area for comparison is covered with sea ice. The difference in the surface $\Omega_{\text {arag }}$ between two versions is quite small. The underestimation decreases significantly toward a depth of about $45 \mathrm{~m}$. The projected $\Omega_{\text {arag }}$ below $45 \mathrm{~m}$ is overestimated by up to $0.2(0.4)$. In comparison with JOIS 08 during ice-free condition, "C ${ }^{4}$ MIP" ("CMIP5") tends to overestimate (underestimate) $\Omega_{\text {arag }}$ by $0.24(0.06)$ at the surface. The surface $\Omega_{\text {arag }}$ in "CMIP5" under ice-free condition of Canada basin corresponds better to the observed value than in " $\mathrm{C}^{4} \mathrm{MIP}$ " under ice-covered condition. Below $60 \mathrm{~m}$, the projected $\Omega_{\text {arag }}$ is greatly overestimated by up to $0.78(0.97)$. The projected average surface $\mathrm{pH}$ in the Arctic Ocean for $\mathrm{C}^{4} \mathrm{MIP}$ and CMIP5 is about $0.05(0.03)$ lower than the observed values.

\subsection{Comparison of physical and carbon-system variables between the two model versions}

The Arctic sea-ice extent projected by the two model versions was compared with that based on the observational dataset of the Hadley Centre sea-ice concentration analysis (HadISST) (Fig. 1). The sea-ice extent is defined here as the total area of grid cells with a sea-ice concentration greater than $15 \%$, as adopted by Wang and Overland (2009). In September, observed sea-ice extent was $9.4 \times 10^{6} \mathrm{~km}^{2}$ in 1950 , which rapidly decreased to $4.6 \times 10^{6} \mathrm{~km}^{2}$ by 2007 . 
"CMIP5" reproduces the observed decrease well from 1970 and projects ice-free condition in September by 2040. In contrast, "C ${ }^{4}$ MIP" overestimates sea-ice extent in September by up to $80 \%$ and projects ice-free condition by 2090. The September ice-free condition by 2040 projected in "CMIP5" is consistent with recent studies (Holland et al., 2006; Stroeve et al., 2007; Wang and Overland, 2009). The projected summer sea-ice reductions for both versions are more rapid than in the Climate System Model CSM1.4-carbon of the US National Center for Atmospheric Research, which was used by Steinacher et al. (2009) and Frölicher and Joos (2010) for analyzing Arctic acidification, in which the sea-ice extent in September is $2.3 \times 10^{6} \mathrm{~km}^{2}$ in 2100 under the SRES A2 scenario. The rapid sea-ice reduction in "CMIP5" results in icefree condition lasting more than 6 months and changing the Arctic Ocean into a seasonal sea-ice zone after 2080, whereas that condition lasts only 2 months in 2100 for " $\mathrm{C}^{4} \mathrm{MIP}$ ".

In March, the observed sea-ice extent is $15.6 \times 10^{6} \mathrm{~km}^{2}$ in 1950 , and gradually decreases to $14.5 \times 10^{6} \mathrm{~km}^{2}$ by 2007 . "CMIP5" ("C ${ }^{4}$ MIP") underestimates (overestimates) sea-ice extent in March; however, the differences in March sea-ice extent between the two model versions and the direct observations are within $10 \%$. The sea-ice extent in March projected by "CMIP5" ("C ${ }^{4}$ MIP") remains greater than $20 \%$ $(70 \%)$ of the observed present-day value until 2100 . The earlier reduction in sea-ice extent in "CMIP5" can be attributed to sea-ice thickness. After spinning-up, the September Arctic sea ice in "CMIP5" is about half as thick as that in " $\mathrm{C}^{4} \mathrm{MIP}$ ". Thus, the decrease of sea-ice extent associated with global warming in "CMIP5" is faster than in "C ${ }^{4}$ MIP", and summer sea-ice-free condition emerges earlier in "CMIP5".

Disappearance of sea ice enhances $\mathrm{CO}_{2}$ uptake through changes in air-sea gas exchange and marine biological productivity due to an increase in sea surface temperature and light penetration. Increased freshwater input due to melting of sea ice dilutes salinity, total $\mathrm{CO}_{2}$ and alkalinity. Thus, "CMIP5" with rapid sea-ice reduction yields an earlier and greater increase in seawater temperature, $\mathrm{CO}_{2}$ uptake, and marine biological productivity, along with decreases in salinity and alkalinity in the Arctic surface waters (Fig. 3). The decrease in DIC in "CMIP5" after 2080 is caused by rapid sea-ice reduction, which leads to a decrease in DIC due to freshwater input and biological processes that counteract the DIC increase due to $\mathrm{CO}_{2}$ uptake. DIC in "C ${ }^{4} \mathrm{MIP}$ " gradually increases, because an increase in DIC due to $\mathrm{CO}_{2}$ uptake exceeds a decrease in DIC due to freshwater input and biological processes.

Furthermore, the partial pressure of carbon dioxide $\left(p \mathrm{CO}_{2}\right)$ in the Arctic surface waters is lower than in the atmosphere, partly because sea ice limits air-sea gas exchange. September $p \mathrm{CO}_{2}$ value in the Arctic surface waters reproduced by the two model versions is about $290 \mu$ atm in the 1990 s (atmospheric $\mathrm{CO}_{2} \approx 360 \mathrm{ppm}$ ), which is consistent with the observations by Jutterström and Anderson (2010), who reported a typical value less than $300 \mu \mathrm{atm}$. A reduction (a)

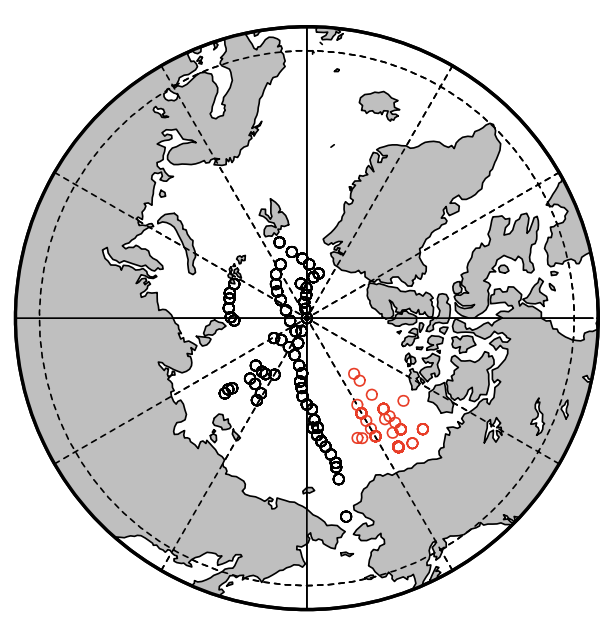

(b)

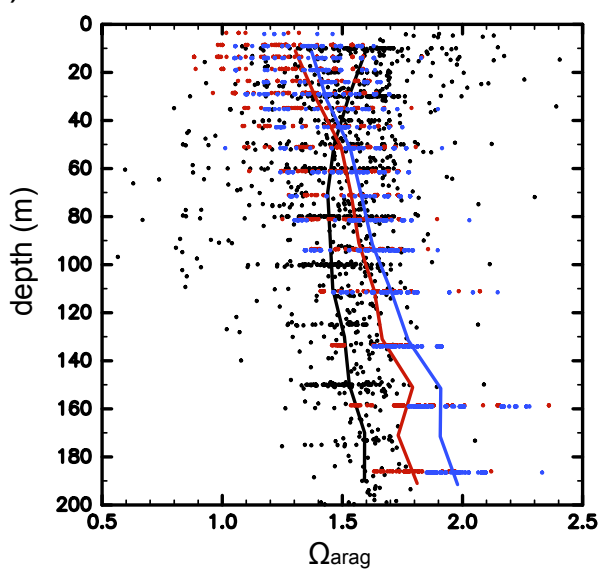

(c)

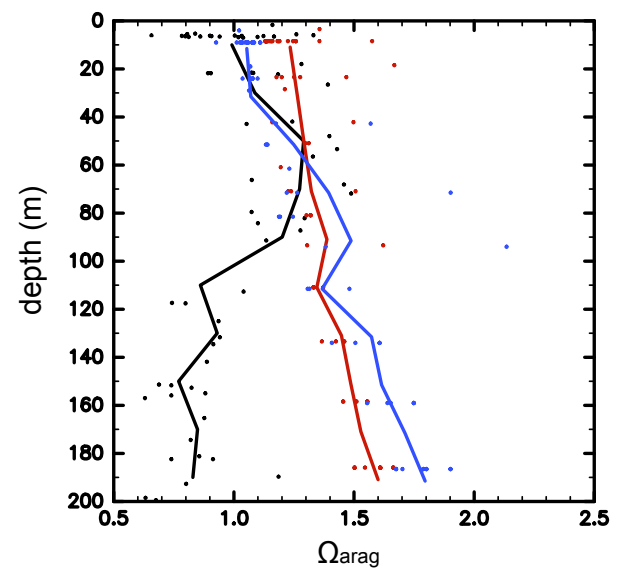

Fig. 3. (a) Observation sites of ODEN-91, AOS-94, and ARCSYS96 (black open circle), and JOIS 2008 (red open circle). The vertical distribution of $\Omega_{\mathrm{arag}}$ calculated from (b) ODEN-91, AOS-94, and ARCSYS-96; and (c) JOIS 2008. The dots represent raw data and lines represent horizontal average. Red and blue show $\Omega_{\text {arag }}$ calculated from " ${ }^{4}$ MIP" and "CMIP5" for the same time and place. 
in sea ice enables the ocean to come closer to equilibrium with the atmosphere. Therefore, when the atmospheric $\mathrm{CO}_{2}$ exceeds $340 \mathrm{ppm}$, the rapid increase in $\mathrm{CO}_{2}$ uptake due to rapid summer sea-ice reduction raises seawater $p \mathrm{CO}_{2}$ in "CMIP5" more than in " $\mathrm{C}^{4} \mathrm{MIP}$ " under the same atmospheric $\mathrm{CO}_{2}$ concentration. The maximum difference in annual mean surface water $p \mathrm{CO}_{2}$ between the two model versions is $80 \mu \mathrm{atm}$ at $520 \mathrm{ppm}$ (year $\approx 2045$, which is a few years after the difference in summer sea-ice extent reaches a maximum). After that, the increase in $p \mathrm{CO}_{2}$ in " $\mathrm{C}^{4} \mathrm{MIP}$ " by $\mathrm{CO}_{2}$ uptake due to summer sea-ice reduction is greater than that in "CMIP5". Thus, the difference in $p \mathrm{CO}_{2}$ between two versions decreased to $50 \mu \mathrm{atm}$ by 2100 . Simulated saturation fractions, defined here as oceanic $p \mathrm{CO}_{2}$ values in terms of fraction of the saturation value with respect to atmospheric $\mathrm{CO}_{2}$ concentration, are less than $80 \%$ before 2000 . The saturation fractions in both versions increased to $90 \%$ near the time when the Arctic Sea becomes ice-free in summer, and then slowly approach $100 \%$.

\subsection{Comparison of $\mathrm{pH}$ and aragonite saturation between two versions}

In this section, we compare the bias-corrected annual mean $\Omega_{\text {arag }}$ and $\mathrm{pH}$ averaged in the Arctic surface waters between our two model versions. The averaged model bias was applied to all model grids of the Arctic surface water, since focus is on the difference in changes of $\Omega_{\mathrm{arag}}$ and $\mathrm{pH}$ resulting from sea-ice reduction averaged across the Arctic Ocean in the two model versions. The model bias subtracted from model projections is not $\Omega_{\text {arag }}$, but rather $T, S$, DIC and Alk, because these four parameters are conserved quantities. The modified DIC $\left(\right.$ DIC $\left._{(\text {mod. }}\right)$ ) after removing model bias is described by $\mathrm{DIC}_{(\text {mod. })}=\mathrm{DIC}_{(\text {model })}-\overline{\mathrm{DIC}}_{\text {(corr. })}-\mathrm{DIC}_{\text {(obs. }}$, where $\mathrm{DIC}_{\text {(model.) }}$ is the value projected in the respective version. $\overline{\left.\operatorname{DIC}_{(\text {corr. })}-\mathrm{DIC}_{(\text {obs. }}\right)}$ is the average model bias of DIC between the observed values $\left(\mathrm{DIC}_{\text {(obs.) }}\right)$ from ODEN91, AOS-94, ARCSYS-96, and JOIS 08, and the model values (DIC (corr.) $)$ corresponding to the place and time of the observations. Seawater temperature, salinity and alkalinity are corrected in the same manner. The bias-corrected $\Omega_{\text {arag }}$ was calculated using these corrected parameters. The calculated model bias of $\Omega_{\text {arag }}$ in 1995 is $-0.3(-0.24)$ in "C ${ }^{4} \mathrm{MIP}$ " ("CMIP5") at the surface.

Under pre-industrial conditions, there is little difference in projected annual mean surface $\mathrm{pH}$ and $\Omega_{\text {arag }}$ averaged over the Arctic between the two versions (Fig. 4). The reduction rates of these two variables for "CMIP5" are faster than those for "C ${ }^{4} \mathrm{MIP}$ " at $\mathrm{CO}_{2}$ concentrations greater than $320 \mathrm{ppm}$, beyond which rapid summer sea-ice reduction starts in "CMIP5". Projected present-day $\mathrm{pH}\left(\Omega_{\text {arag }}\right)$ in "CMIP5" is $0.05(0.1)$ lower than that in "C ${ }^{4}$ MIP". Annual mean $\Omega_{\text {arag }}$ in "C $\mathrm{C}^{4} \mathrm{MIP}$ " ("CMIP5") becomes less than one at 606 (513) ppm at year 2056 (2046). The maximum differences in $\mathrm{pH}$ and $\Omega_{\text {arag }}$ between the two versions are 0.1 and (a)
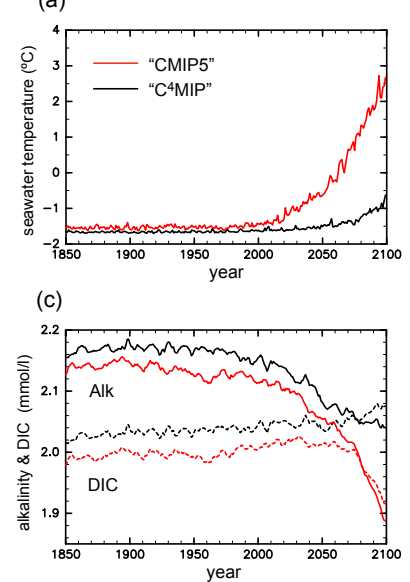

(e)

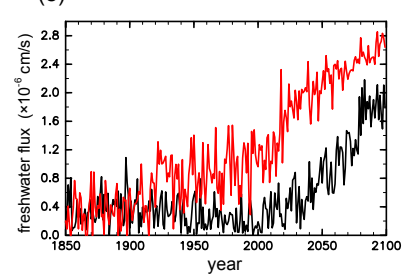

(g)

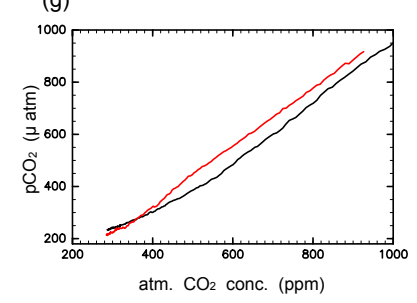

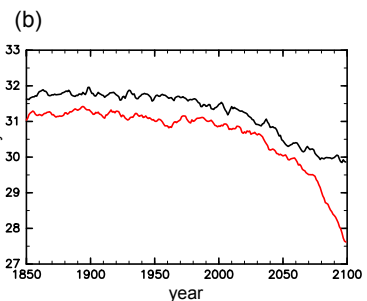

(d)

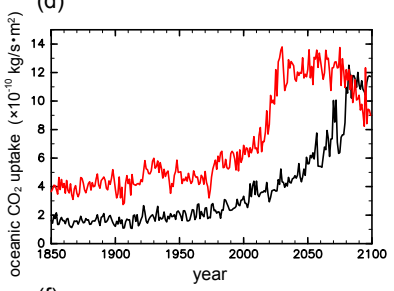

(f)

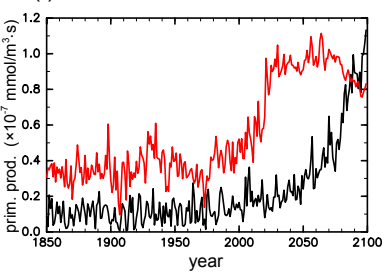

(h)

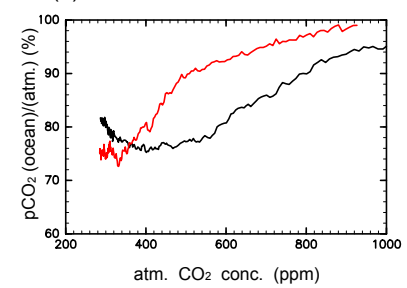

Fig. 4. Calculated annual mean, (a) seawater temperature, (b) salinity, (c) alkalinity and DIC, (d) oceanic $\mathrm{CO}_{2}$ uptake, (e) freshwater input, (f) primary production, (g) seawater $p \mathrm{CO}_{2}$, and (h) fraction of $p \mathrm{CO}_{2}$ between ocean and atmosphere at the Arctic surface for "C ${ }^{4}$ MIP" (black) and "CMIP5" (red) model versions. These results are not drift- corrected.

0.21 , respectively, at $520 \mathrm{ppm}$ when the difference in seawater $p \mathrm{CO}_{2}$ for the two versions reaches a maximum. These results indicate that the reductions in $\mathrm{pH}$ and $\Omega_{\text {arag }}$ in the Arctic surface waters are significantly accelerated by rapid sea-ice reduction. Differences in $\mathrm{pH}$ and $\Omega_{\mathrm{arag}}$ between the two model versions decrease at atmospheric $\mathrm{CO}_{2}$ concentrations greater than $520 \mathrm{ppm}$. The difference in $\Omega_{\text {arag }}$ decreases to 0.1 at $900 \mathrm{ppm}$, whereas that of $\mathrm{pH}$ decreases only slightly. We discuss what causes these different responses of $\mathrm{pH}$ and $\Omega_{\text {arag }}$ in Sect. 4.2.

The areal fractions of undersaturated surface seawater with respect to aragonite in the Arctic Ocean for the two model versions are calculated as an index for identifying atmospheric $\mathrm{CO}_{2}$ concentration, beyond which acidification may cause serious consequences (Fig. 5). This was done to help establish firm criteria for atmospheric $\mathrm{CO}_{2}$ concentrations that prevent widespread aragonite dissolution. The 
(a)

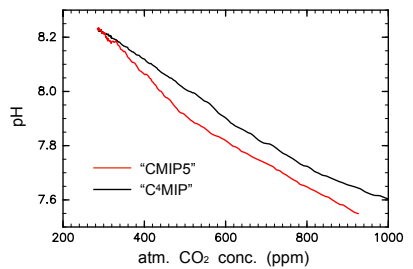

(b)

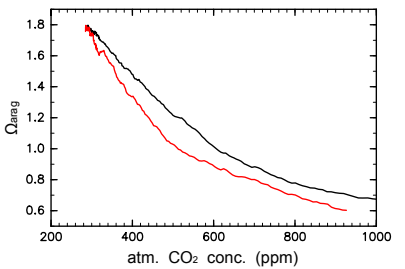

Fig. 5. Change in modified annual mean of (a) $\mathrm{pH}$ and (b) $\Omega_{\mathrm{arag}}$ with atmospheric $\mathrm{CO}_{2}$ concentration in the Arctic surface waters for "C ${ }^{4}$ MIP" (black) and "CMIP5" (red) model versions.

bias-corrected $\Omega_{\text {arag }}$ also is used for this calculation. About $10 \%$ of the surface waters in "C ${ }^{4}$ MIP" ("CMIP5") is projected to become undersaturated with respect to aragonite in at least one month of the years when atmospheric $\mathrm{CO}_{2}$ reaches 408 (365) ppm. At $\mathrm{CO}_{2}$ levels of 458 (425) ppm, $10 \%$ of the surface area in "C ${ }^{4} \mathrm{MIP}$ " ("CMIP5") is projected to become undersaturated throughout the year. More than $50 \%$ of the surface area becomes undersaturated at 600 (540) ppm, and the entire surface area becomes undersaturated year-round at 740 (680) ppm. The extension of undersaturated surface seawater also is influenced by sea-ice reduction rate. Adopting a criterion of year-round undersaturated seawater in $10 \%$ of the surface area in the Arctic Ocean (Steinacher et al., 2009) and the rapid sea-ice reduction as projected by "CMIP5", the atmospheric $\mathrm{CO}_{2}$ concentration should not exceed $425 \mathrm{ppm}$.

As mentioned in introduction, climate models submitted to IPCC AR4 tend to yield slower sea ice decrease than recently observed by satellite, and predicted that summer sea-ice-free condition will be achieved by the end of the 21 st century or even later. If the reduction of summer sea-ice extent in the Arctic Ocean keeps its present pace, these models underestimate not only the reduction rate of sea ice, but also that of $\mathrm{pH}$ and $\Omega_{\text {arag }}$.

We also contrast the results of RCP4.5 and RCP8.5 in "CMIP5". As for temporal variation, the reduction rates of $\mathrm{pH}$ and $\Omega_{\text {arag }}$ under RCP8.5 are considerably faster than under RCP4.5 owing to much higher atmospheric $\mathrm{CO}_{2}$ concentration and earlier sea-ice reduction under RCP8.5. With respect to variation with atmospheric $\mathrm{CO}_{2}$ concentration, however, similar reduction rate of summer sea-ice extent is predicted under both scenarios. This means that air-sea $\mathrm{CO}_{2}$ exchange in the Arctic surface waters under RCP4.5 becomes closer to equilibrium than under RCP8.5 because of slower increase in atmospheric $\mathrm{CO}_{2}$ concentration. Consequently, annual mean $\mathrm{pH}\left(\Omega_{\text {arag }}\right)$ under RCP4.5 is 0.02 (0.03) lower than under RCP8.5 at the maximum. These reductions are less than the $\mathrm{pH}\left(\Omega_{\mathrm{arag}}\right)$ decrease of $0.1(0.21)$ due to rapid sea-ice reduction. Our results suggest that the uncertainty of $\mathrm{pH}$ and $\Omega_{\text {arag }}$ reduction caused by difference in sea-ice reduction rate is more serious than by that in $\mathrm{CO}_{2}$ emission scenario under the same atmospheric $\mathrm{CO}_{2}$ concentration.

\section{Discussion}

\subsection{Which mechanisms reduce $\mathrm{pH}$ and $\boldsymbol{\Omega}_{\text {arag }}$ due to rapid sea-ice reduction?}

The factors affecting $\mathrm{pH}$ and $\Omega_{\text {arag }}$ are seawater temperature $(T)$, salinity $(S), \mathrm{CO}_{2}$ uptake by gas exchange with the atmosphere (Gas), freshwater input $(\mathrm{Fw})$, biology (Bio) and transport of carbon by lateral and vertical seawater exchange (Trans). To quantify the effects of these factors on the reductions in $\mathrm{pH}$ and $\Omega_{\text {arag }}$ in the top $50 \mathrm{~m}$ of the Arctic Ocean due to rapid sea-ice reduction, we divide the changes in $\mathrm{pH}$ and $\Omega_{\text {arag }}$ into components corresponding to the six factors for each model result. $\Omega_{\text {arag }}(\mathrm{pH})$ is represented by

$\Omega_{\text {arag }}=F(T, S$, DIC, alk $)$,

where $F$ is a function describing the relation between $\Omega_{\text {arag }}$ and the four variables on the right-hand side. Gas exchange, freshwater input, biology and carbon transport affect $\mathrm{pH}$ and $\Omega_{\text {arag }}$ through changes in alkalinity and/or DIC. Incremental change of $\Omega_{\text {arag }}(\mathrm{pH})$ can be expressed by the following equation:

$$
\begin{aligned}
\Delta \Omega_{\text {arag }} & =\frac{\partial \Omega_{\text {arag }}}{\partial T} \Delta T+\frac{\partial \Omega_{\text {arag }}}{\partial S} \Delta S+\frac{\partial \Omega_{\text {arag }}}{\partial \mathrm{DIC}} \Delta \mathrm{DIC}_{\text {gas }} \\
& +\frac{\partial \Omega_{\text {arag }}}{\partial \mathrm{DIC}} \Delta \mathrm{DIC}_{\mathrm{Fw}}+\frac{\partial \Omega_{\text {arag }}}{\partial \mathrm{Alk}} \Delta \mathrm{Alk}_{\mathrm{Fw}} \\
& +\frac{\partial \Omega_{\text {arag }}}{\partial \mathrm{DIC}} \Delta \mathrm{DIC}_{\mathrm{Bio}}+\frac{\partial \Omega_{\mathrm{arag}}}{\partial \mathrm{Alk}} \Delta \mathrm{Alk}_{\mathrm{Bio}} \\
& +\frac{\partial \Omega_{\text {arag }}}{\partial \mathrm{DIC}} \Delta \mathrm{DIC}_{\text {Trans }}+\frac{\partial \Omega_{\text {arag }}}{\partial \mathrm{Alk}} \Delta \mathrm{Alk}_{\text {Trans }},
\end{aligned}
$$

where $\Delta$ denotes incremental change of variables in Eq. (1). $\Delta \mathrm{DIC}_{\text {gas }}$ is calculated by integrating annual $\mathrm{CO}_{2}$ flux into the ocean. Similarly, $\triangle \mathrm{DIC} \mathrm{Fw}_{\mathrm{F}}$ and $\Delta \mathrm{Alk}_{\mathrm{Fw}}$ are obtained by integrating annual freshwater flux into the ocean, and $\triangle \mathrm{DIC}_{\mathrm{Bio}}$ and $\triangle \mathrm{Alk}_{\mathrm{Bio}}$ by integrating the terms describing carbon exchange in the ocean ecosystem model, such as phytoplankton respiration, phytoplankton photosynthesis, zooplankton excretion, detritus remineralization, and $\mathrm{CaCO}_{3}$ formation. The first term on the right side of the equation in certain years is evaluated by the following equation:

$$
\begin{aligned}
& \frac{\partial \Omega_{\text {arag }}}{\partial T} \Delta T_{(\mathrm{yr})} \cong\left\{\Omega_{\text {arag }}\left(T_{(\mathrm{yr})}, S_{(\mathrm{yr}-1)}, \mathrm{DIC}_{(\mathrm{yr}-1)}, \mathrm{Alk}_{(\mathrm{yr}-1)}\right)\right. \\
& \quad-\Omega_{\text {arag }}\left(T_{(\mathrm{yr}-1)}, S_{(\mathrm{yr}-1)}, \mathrm{DIC}_{(\mathrm{yr}-1)}, \mathrm{Alk}_{(\mathrm{yr}-1)}\right) \\
& \quad+\Omega_{\text {arag }}\left(T_{(\mathrm{yr})}, S_{(\mathrm{yr})}, \mathrm{DIC}_{(\mathrm{yr})}, \mathrm{Alk}_{(\mathrm{yr})}\right) \\
& \left.\quad-\Omega_{\text {arag }}\left(T_{(\mathrm{yr}-1)}, S_{(\mathrm{yr})}, \mathrm{DIC}_{(\mathrm{yr})}, \mathrm{Alk}_{(\mathrm{yr})}\right)\right\} \times \frac{1}{2},
\end{aligned}
$$

where subscript yr denotes the target year. All of the terms except the transport term are evaluated in a similar manner. The transport term is calculated as the residual. $\mathrm{pH}$ also is divided into six components in a way similar to $\Omega_{\text {arag }}$. The contribution of these components to $\Omega_{\text {arag }}$ and $\mathrm{pH}$ for the two model versions is integrated from 1850 to 2045 


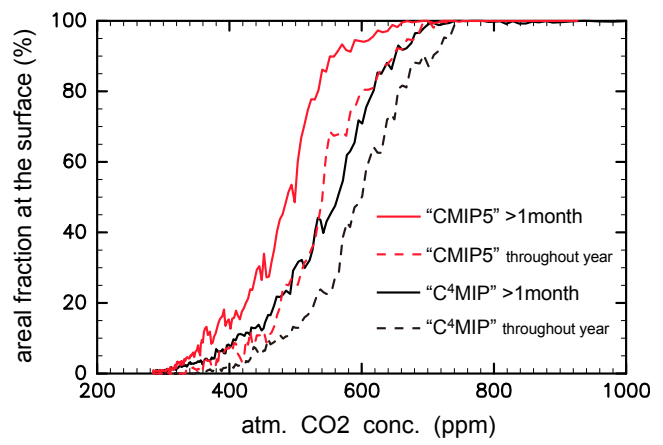

Fig. 6. The evolution of the areal fraction of undersaturated surface water with atmospheric $\mathrm{CO}_{2}$ concentration for " $\mathrm{C}^{4} \mathrm{MIP}$ " (black) and "CMIP5" (red) model versions. The solid and dashed lines represent evolution in at least one month of the year and throughout the year, respectively.

$\left(\mathrm{CO}_{2} \approx 520 \mathrm{ppm}\right.$, where the differences in $\mathrm{pH}$ and $\Omega_{\text {arag }}$ between the two model versions reach a maximum) to identify the main factors responsible for reducing $\mathrm{pH}$ and $\Omega_{\mathrm{arag}}$ with rapid sea-ice reduction (Fig. 6). The terms are calculated for the uppermost $50 \mathrm{~m}$. Gas exchange and transport terms are combined and plotted as "storage", because they nearly cancel each other.

$\Omega_{\text {arag }}$ for the Arctic Ocean decreases due to $\mathrm{CO}_{2}$ uptake by gas exchange and dilution by freshwater input, and increases due to biological activity, seawater warming, freshening, and transport of carbon out of the top $50 \mathrm{~m}$ by lateral and vertical seawater exchanges. In both versions, more than $80 \%$ of the total reduction in $\Omega_{\text {arag }}$ is due to the storage of anthropogenic carbon, and the freshwater contributes less than $20 \%$. For the change in $\mathrm{pH}$, seawater warming reduces $\mathrm{pH}$, and the other five factors affect $\mathrm{pH}$ as they do $\Omega_{\mathrm{arag}}$. The reduction in $\mathrm{pH}$ in the Arctic surface waters is mainly caused by increased storage of anthropogenic carbon due to $\mathrm{CO}_{2}$ uptake.

The rapid sea-ice reduction affects remarkably each mechanism, as mentioned in Sect. 3.2. In order to investigate the mechanisms decreasing $\mathrm{pH}$ and $\Omega_{\text {arag }}$ due to rapid sea-ice reduction, we calculate the differences in total changes in $\mathrm{pH}$ and $\Omega_{\mathrm{arag}}$, and contribution of each mechanism between two versions (Table 2a). As to $\Omega_{\text {arag }}$, increase of anthropogenic carbon storage lowers $\Omega_{\text {arag }}$ by 0.2 , and freshwater input does by 0.067 . This increase in carbon storage is not attributed to decrease in transport of carbon out of the top $50 \mathrm{~m}$ by advection and diffusion, but increase in $\mathrm{CO}_{2}$ uptake by gas exchange. Therefore, the analysis suggests that rapid sea-ice reduction decreases $\Omega_{\text {arag }}$ by increases in both storage of anthropogenic carbon by gas exchange and freshwater input. The decreases in $\Omega_{\text {arag }}$ through these two mechanisms are partly $(\approx 20 \%)$ canceled out by the increase by biological production. In terms of $\mathrm{pH}$, besides the effects of $\mathrm{CO}_{2}$ storage and fresh water input, an increase in seawater temperature decreases $\mathrm{pH}$.

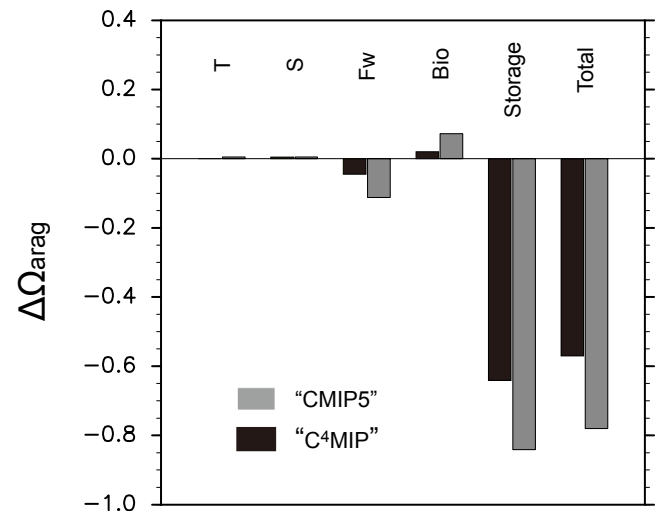

Fig. 7. Projected changes in the annual mean difference $\Omega_{\text {arag }}$ from 1850 to $2045\left(\mathrm{CO}_{2} \approx 520 \mathrm{ppm}\right)$ in the top $50 \mathrm{~m}$ of the Arctic Ocean for "C $\mathrm{C}^{4} \mathrm{MIP}$ " (black) and "CMIP5" (gray). The total change is divided into contributions by changes in seawater temperature $(T)$, salinity $(S), \mathrm{CO}_{2}$ uptake by gas exchange (Gas), freshwater input $(\mathrm{FW})$, biology (Bio) and transport of carbon by lateral and vertical seawater exchange (Trans). For the gas exchange and transport terms, only the sum of the two (defined as "storage") is plotted.

\subsection{Different responses of $\mathrm{pH}$ and $\boldsymbol{\Omega}_{\text {arag }}$ to high atmospheric $\mathrm{CO}_{2}$ concentration}

As shown in Sect. 3.3, the difference in $\mathrm{pH}$ in the Arctic surface waters between the two versions stays approximately the same from $\mathrm{CO}_{2}$ concentrations of $520 \mathrm{ppm}$ to $900 \mathrm{ppm}$, whereas that in $\Omega_{\text {arag }}$ decreases by half (Fig. 4). We also calculate the differences in total changes in $\mathrm{pH}$ and $\Omega_{\text {arag }}$, and contribution of each mechanism at atmospheric $\mathrm{CO}_{2}$ concentration of $900 \mathrm{ppm}$ (Table 2b). The storage of anthropogenic carbon, which is the main reason of different projections of $\mathrm{pH}$ and $\Omega_{\text {arag }}$ at $520 \mathrm{ppm}$, is decreased to about $30 \%$ from $520 \mathrm{ppm}$ to $900 \mathrm{ppm}$. This decrease is contributed to the decrease in difference of $p \mathrm{CO}_{2}$ between two versions from 80 to $50 \mu \mathrm{atm}$. In addition, the decrease dependences of $\mathrm{pH}$ and $\Omega_{\text {arag }}$ on $p \mathrm{CO}_{2}$ weaken as $p \mathrm{CO}_{2}$ increases (Fig. 7). Through these two effects, the decrease in storage effect diminishes the gap of predicted $\Omega_{\text {arag }}$ between two versions at $900 \mathrm{ppm}$. On the other hand, for $\mathrm{pH}$, the decrease in storage effect is partly canceled out by the increase in seawater temperature effect. The different behavior between $\mathrm{pH}$ and $\Omega_{\text {arag }}$ at high atmospheric $\mathrm{CO}_{2}$ concentration is caused by the difference response to the seawater warming.

\subsection{The relationship between seasonal cycle of $\Omega_{\mathrm{arag}}$ and sea-ice reduction}

The seasonal cycle of surface $\Omega_{\text {arag }}$ in the Arctic Ocean also is affected by sea-ice reduction in the simulations (Fig. 9). In the Arctic surface waters, summer (winter) $\Omega_{\text {arag }}$ for the decade 1990-1999 in the two versions is lowest (highest) in the annual excursion, which is out of phase with a typical seasonal cycle of $\Omega_{\text {arag }}$ in the Northern Hemisphere. 
Table 2. Difference in projected changes in the annual mean $\Omega_{\text {arag }}$ from 1850 to (a) 2045 and (b) 2090 in the top $50 \mathrm{~m}$ of the Arctic Ocean between "C ${ }^{4} \mathrm{MIP}$ " and new "CMIP5". The total change is divided into 5 factors as mentioned in Fig. 6.

\begin{tabular}{|c|c|c|c|c|c|c|}
\hline \multicolumn{7}{|l|}{ (a) $520 \mathrm{ppm}$} \\
\hline & $T$ & $S$ & Bio & Fw & Storage & Total \\
\hline $\begin{array}{l}\mathrm{pH} \\
\left(\mathrm{C}^{4} \mathrm{MIP}-\mathrm{CMIP} 5\right)\end{array}$ & -0.024 & +0.005 & +0.01 & -0.013 & -0.087 & -0.11 \\
\hline $\begin{array}{l}\Omega_{\text {arag }} \\
\left(\mathrm{C}^{4} \mathrm{MIP}-\mathrm{CMIP} 5\right)\end{array}$ & +0.0045 & +0.0005 & +0.052 & -0.067 & -0.2 & -0.21 \\
\hline \multicolumn{7}{|l|}{ (b) $900 \mathrm{ppm}$} \\
\hline & $T$ & $S$ & Bio & Fw & Storage & Total \\
\hline $\begin{array}{l}\mathrm{pH} \\
\left(\mathrm{C}^{4} \mathrm{MIP}-\mathrm{CMIP} 5\right)\end{array}$ & -0.06 & +0.015 & +0.013 & -0.017 & -0.034 & -0.09 \\
\hline $\begin{array}{l}\Omega_{\text {arag }} \\
\left(\mathrm{C}^{4} \text { MIP-CMIP5) }\right.\end{array}$ & +0.016 & -0.003 & +0.063 & -0.097 & -0.077 & -0.1 \\
\hline
\end{tabular}

(a)

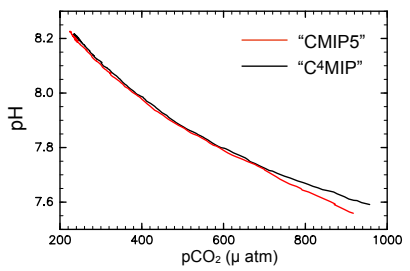

(b)

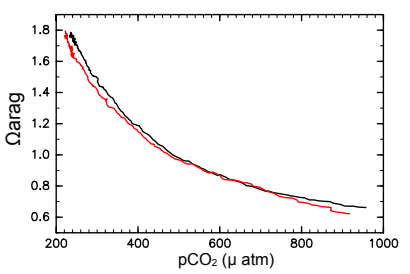

Fig. 8. Calculated annual mean (a) $\mathrm{pH}$ and (b) $\Omega_{\text {arag }}$ with seawater $p \mathrm{CO}_{2}$ in the Arctic surface waters for "C $\mathrm{C}^{4} \mathrm{MIP}$ " (black) and "CMIP5" (red).

The amplitude of seasonal variability is less than 0.1 , which is consistent with the results reported by Steinacher et al. (2009). This seasonal cycle of $\Omega_{\text {arag }}$ is driven mainly by air-sea $\mathrm{CO}_{2}$ exchange and freshwater input. The increases in $\mathrm{CO}_{2}$ uptake and freshwater input during summer due to summer sea-ice melting reduce $\Omega_{\text {arag }}$.

The seasonal amplitude of freshwater input is weakened by sea-ice reduction. The seawater temperature is raised during summer sea-ice-free condition, which increases $\Omega_{\text {arag }}$. The increase in winter air-sea $\mathrm{CO}_{2}$ exchange consequent to winter sea-ice reduction decreases the seasonal variability of air-sea $\mathrm{CO}_{2}$ exchange. From these three effects, the amplitude of seasonal variation in $\Omega_{\text {arag }}$ is decreased to 0.04 by the year 2060 (2090) in "CMIP5" ("C ${ }^{4}$ MIP"). This weakening of seasonal variation is not reported by previous studies, probably because their sea-ice reduction is slower than in our model.

Further on, the significant winter sea-ice reduction enables winter $\mathrm{CO}_{2}$ uptake and reverses the seasonal cycle of air-sea gas exchange. After the year 2065 in "CMIP5", the Arctic surface waters absorb $\mathrm{CO}_{2}$ more in winter than in summer.

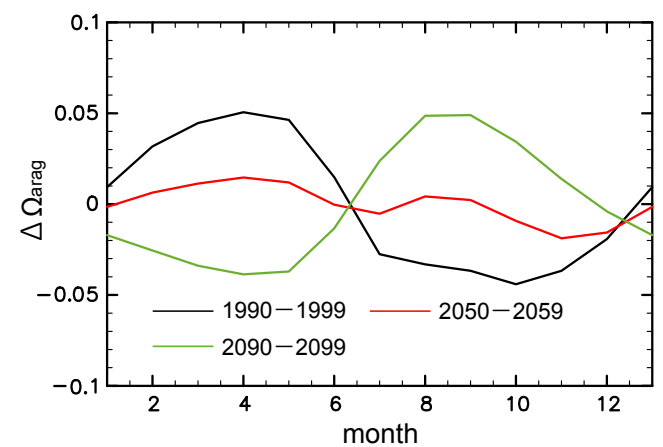

Fig. 9. Calculated seasonal deviation in $\Omega_{\text {arag }}$ in the Arctic Ocean in "CMIP5" from the annual mean for 1990-1999 (black), 2050-2059 (red), and 2090-2099 (green).

Thus, $\Omega_{\text {arag }}$ is decreased in winter due to an increase in $\mathrm{CO}_{2}$ uptake and seawater cooling, whereas it is increased in the summer due to seawater warming. This seasonal cycle of $\Omega_{\text {arag }}$ is the same phase of that in the Northern Hemisphere. In "CMIP5" for the decade 2090-2099, summer (winter) $\Omega_{\text {arag }}$ is about 0.05 higher (lower) than the annual mean value. This change in seasonal cycle of $\Omega_{\text {arag }}$ is not found in "C ${ }^{4} \mathrm{MIP}$ ", in which reduction of sea-ice extent relative to the present day is only $30 \%$ at about the year 2100 .

\subsection{The effect of model drift on projected $\mathrm{pH}$ and $\boldsymbol{\Omega}_{\mathrm{arag}}$}

As mentioned in Sect. 2.1, the ocean carbon cycle drifts in the two versions of ESM are larger than the OCMIP standard. In order to estimate the effect of ocean carbon drift on the projected $\mathrm{pH}$ and $\Omega_{\mathrm{arag}}$, we estimate an impact on surface ocean chemistry when the amount of carbon corresponding to the drift is uniformly added to the top $300 \mathrm{~m}$ waters. The ocean carbon drift of $-0.2(-0.05) \mathrm{PgC} \mathrm{yr}^{-1}$ in 
"C $\mathrm{C}^{4} \mathrm{MIP}$ " ("CMIP5") is then equivalent to increase in DIC of $-0.15(-0.04) \mu \mathrm{mol} \mathrm{kg}^{-1} \mathrm{yr}^{-1}$. In the Arctic surface waters, $\mathrm{pH}$ in "C $\mathrm{C}^{4} \mathrm{MIP}$ " ("CMIP5") at the year 2100 is increased by $+0.01(+0.005)$ and $\Omega_{\text {arag }}$ by $+0.05(+0.02)$ according to the DIC increase estimated above. These shifts are sufficiently small and, moreover, act to expand the differences of $\mathrm{pH}$ and $\Omega_{\text {arag }}$ between two versions of ESM. It can therefore be concluded that the drift of ocean carbon cycle in our ESMs does not change our main argument that the reductions of $\mathrm{pH}$ and $\Omega_{\text {arag }}$ in the Arctic surface waters are significantly affected by the reduction rate of sea-ice extent.

\section{Conclusions}

Impacts of sea-ice reduction on the future projection of $\mathrm{pH}$ and aragonite saturation values in the Arctic surface waters have been investigated. We compared the rates of ocean acidification calculated from outputs of two versions of an Earth system model, in which summer Arctic ice-free condition by 2040 and 2090, respectively, is projected under similar $\mathrm{CO}_{2}$ emission scenarios. Results indicated that the maximum differences in $\mathrm{pH}$ and $\Omega_{\text {arag }}$ between the two model versions are 0.1 and 0.21 , respectively, at atmospheric $\mathrm{CO}_{2}$ levels of $520 \mathrm{ppm}$ (year $\approx 2045$, a few years after the difference in summer sea-ice extent reaches a maximum). The critical atmospheric $\mathrm{CO}_{2}$ concentration, at which the Arctic surface waters become undersaturated with respect to aragonite in annual mean, is reduced from 606 to $513 \mathrm{ppm}$ due to rapid sea-ice reduction. In the classification of $\mathrm{CO}_{2}$ stabilization scenarios by IPCC AR4, this decrease in critical $\mathrm{CO}_{2}$ concentration corresponds to a shift from category $\mathrm{V}$ to IV (IPCC, 2007). The earlier emergence of undersaturated surface water due to rapid sea-ice reduction is a significant factor to be considered in determining $\mathrm{CO}_{2}$ stabilization concentration.

The analysis showed that rapid sea-ice reduction decreases $\mathrm{pH}$ and aragonite saturation state due to increases in both $\mathrm{CO}_{2}$ uptake by air-sea gas exchange and freshwater input from an increase in sea-ice meltwater. Comparison between the two model versions reveals that $\mathrm{CO}_{2}$ uptake and freshwater input reduce aragonite saturation state due to rapid sea-ice reduction, and about $20 \%$ of these contributions are canceled out by an increase in biological processes.

For the seasonal variability of $\Omega_{\text {arag }}$, the sea-ice reduction weakens the seasonal amplitude because seasonal variability in freshwater input and $\mathrm{CO}_{2}$ uptake decreases, and that in seawater temperature increases. Furthermore, the change in the seasonal cycle of $\mathrm{CO}_{2}$ uptake due to winter sea-ice reduction reverses the seasonal cycle of $\Omega_{\text {arag. }}$. These changes in seasonal amplitude and cycle of $\Omega_{\text {arag }}$ are also affected by the rapidity of sea-ice reduction

Our results indicate that future projections of $\mathrm{pH}$ and aragonite saturation state in Arctic surface waters can be influenced significantly by the rapidity of sea-ice reduction as well as by increases in atmospheric $\mathrm{CO}_{2}$ concentrations. We emphasize that accurate modeling of sea-ice dynamics is crucial for projections related to not only global warming, but also ocean acidification for the Arctic Ocean.

Acknowledgements. The authors would like to thank two referees for their constructive comments on the original manuscript. We are also thankful to Michiyo Yamamoto-Kawai and Fiona A. McLaughlin for providing the observation datasets for the Joint Ocean Ice Study (JOIS) 2008. This study was supported by the Innovative Program of Climate Change Projection for the $21 \mathrm{st}$ Century, MEXT, Japan. The numerical simulations in this study were performed using the Earth Simulator, and all the figures were produced with the GFD-DENNOU Library.

Edited by: L. Bopp

\section{References}

Bates, N. R., Mathis, J. T., and Cooper, L. W.: Ocean acidification and biologically induced seasonality of carbonate mineral saturation states in the western Arctic Ocean, J. Geophys. Res., 114, C11007, doi:10.1029/2008JC004862, 2009.

Feely, R. A., Sabine, C. L., Hernandez-Ayon, M., Ianson, D., and Hales, B.: Evidence for Upwelling of Corrosive "Acidified" Water onto the Continental Shelf, Science, 320, 1490-1492, 2008.

Friedlingstein, P., Cox, P., Betts, R., Bopp, L., Von Bloh, W., Brovkin, V., Cadule, P., Doney, S., Eby, M., Fung, I., Bala, G., John, J., Jones, C., Joos, F., Kato, T., Kawamiya, M., Knorr, W., Lindsay, K., Matthews, H. D., Raddatz, T., Rayner, P., Reick, C., Roeckner, E., Schnitzler, K. G., Schnur, R., Strassmann, K., Weaver, A. J., Yoshikawa, C., and Zheng, N.: Climate-Carbon Cycle Feedback Analysis: Results from the $\mathrm{C}^{4} \mathrm{MIP}$ Model Intercomparison: Evolution of carbon sinks in a changing climate, J. Climate, 19, 3337-3343, 2006.

Frölicher, T. L. and Joos, F.: Reversible and irreversible impacts of greenhouse gas emissions in multi-century projections with the NCAR global coupled carbon cycle-climate model, Clim. Dynam., 35, 1439-1459, doi:10.1007/s00382-009-0727-0, 2010.

Gangst $\varnothing$, R., Gehlen, M., Schneider, B., Bopp, L., Aumont, O., and Joos, F.: Modeling the marine aragonite cycle: changes under rising carbon dioxide and its role in shallow water $\mathrm{CaCO}_{3}$ dissolution, Biogeosciences, 5, 1057-1072, doi:10.5194/bg-5-10572008, 2008.

Holland, M. M., Bitz, C. M., and Tremblay, B.: Future abrupt reductions in the summer Arctic sea ice, Geophys. Res. Lett., 33, L23503, doi:10.1029/2006GL028024, 2006.

Hunke, E. and Dukowicz, J. K.: An elastic-viscous-plastic model for sea ice dynamics, J. Phys. Oceanogr., 27, 1849-1867, 1997.

Intergovernmental Panel on Climate Change (IPCC): Climate Change 2007: The Physical Science Basis, in: Contribution of Working Group I to the Fourth Assessment Report of the Intergovernmental Panel on Climate Change, edited by: Solomon, S., Qin, D., Manning, M., Chen, Z., Marquis, M., Averyt, K. B., Tignor, M., and Miller, H. L., Cambridge University Press, Cambridge, UK, 996 pp., 2007. 
Ishimatsu, A., Hayashi, M., Lee, K.-S., Kikkawa, T., and Kita, J.: Physiological effects on fishes in a high- $\mathrm{CO}_{2}$ world, J. Geophys. Res., 110, C09S09, doi:10.1029/2004JC002564, 2005.

Ito, A. and Oikawa, T.: A simulation model of the carbon cycle in land ecosystems Sim-CYCLE: A description based on drymatter production theory and plot-scale validation, Ecol. Modell., 151, 147-179, 2002.

Jutterström, S. and Anderson L. G.: Uptake of $\mathrm{CO}_{2}$ by the Arctic Ocean in a changing climate, Mar. Chem., 122, 96-104, 2010.

K-1 Model Developers: K-1 Coupled GCM (MIROC) description, K-1 Tech. Rep. 1, Cent. for Clim. Syst. Res. (Univ. of Tokyo), Natl. Inst. for Environ. Stud., and Frontier Res. Cent. for Global Change, Yokohama, Japan, available at: http://www. ccsr.u-tokyo.ac.jp/kyosei/hasumi/MIROC/tech-repo.pdf, 2004.

Kawamiya, M., Kishi, M. J., and Suginohara, N.: An ecosystem model for the North Pacific embedded in a general circulation model Part II: Mechanisms forming seasonal variations of chlorophyll, J. Mar. Syst., 25, 159-178, 2000.

Kawamiya, M., Yoshikawa, C., Kato, T., Sato, H., Sudo, K., Watanabe, S., and Matsuno, T.: Development of an integrated Earth system model on the earth simulator, Journal of Earth Simulator, 4, 18-30, available at: http://www.jamstec.go.jp/esc/publication/ journal/jes_vol.4/index.html, 2005.

Locarnini, R. A., Mishonov, A. V., Antonov, J. I., Boyer, T. P., and Garcia, H. E.: World Ocean Atlas 2005, Vol. 1, Temperature, NOAA Atlas NESDIS 61, edited by: Levitus, S., US Govt. Print. Off., Washington, D. C., 2006.

Marland, G., Boden, T. A., and Andres, R. J.: Global, regional, and national $\mathrm{CO}_{2}$ emissions, Trends: A compendium of data on global change, Carbon Dioxide Inf. Anal. Cent., Oak Ridge Natl. Lab, US Dep. of Energy, Oak Ridge, Tennessee, 2005.

McNeil, B. I. and Matear, R. J.: Southern ocean acidification: a tipping point at $450-\mathrm{ppm}$ atmospheric $\mathrm{CO}_{2}$, Proc. Natl. Acad. Sci., 105, 18860-18864, 2008.

Millero, F. J.: Thermodynamics of the carbon dioxide system in the oceans, Geochim. Cosmochim. Ac., 59, 661-677, 1995.

Moss, R. H., Edmonds, J. A., Hibbard, K. A., Manning, M. R., Rose, S. K., van Vuuren, D. P., Carter, T. R., Emori, S., Kainuma, M., Kram, T., Meehl, G. A., Mitchell, J. F. B., Nakicenovic, N., Riahi, K., Smith, S. J., Stouffer, R. J., Thomson, A. M., Weyant, J. P., and Wilbanks, T. J.: The next generation of scenarios for climate change research and assessment, Nature, 463, 747-756, doi:10.1038/nature08823, 2010.

Mucci, A.: The solubility of calcite and aragonite in seawater at various salinities, temperatures and 1 atmosphere total pressure, Am. J. Sci., 238, 780-799, 1983.

Orr, J. C.: Global Ocean Storage of Anthropogenic Carbon (GOSAC), Tech. Rep., IPSL/CNRS, 2002.

Orr, J. C., Najjar, R., Sabine, C. L., and Joos, F.: Abiotic-HOWTO, internal OCMIP report, 25 pp., LSCE/CEA Saclay, Gif-surYvette, France, 1999.

Orr, J. C., Fabry, V. J., Aumont, O., Bopp, L., Doney, S. C., Feely, R. A., Gnanadesikan, A., Gruber, N., Ishida, A., Joos, F., Key, R. M., Lindsay, K., Maier-Reimer, E., Matear, R., Monfray, P., Mouchet, A., Najjar, R. G., Plattner, G.-K., Rodgers, K. B., Sabine, C. L., Sarmiento, J. L., Schlitzer, R., Slater, R. D., Totterdell, I. J., Weirig, M. F., Yamanaka, Y., and Yool, A.: Anthropogenic ocean acidification over the twenty-first century and its impact on calcifying organisms, Nature, 437, 681-686, 2005.
Oschlies, A.: Model-derived estimates of new production: New results point towards lower values, Deep-Sea Res. Pt II, 48, 2173 2197, 2001.

Oschlies, A. and Garcon, V.: An eddy-permitting coupled physicalbiological model of the North Atlantic 1 . Sensitivity to advection numerics and mixed layer physics, Global Biogeochem. Cy., 13, 135-160, 1999.

Riley, J. P. and Tongudai, M.: The major cation/chlorinity ratios in sea water, Chem. Geol., 2, 263-269, 1967.

Royal Society: Ocean acidification due to increasing atmospheric carbon dioxide, The Royal society, London, 223 pp., 2005.

Sabine, C. L., Feely, R. A., Gruber, N., Key, R. M., Lee, K., Bullister, J. L., Wanninkhof, R., Wong, C. S., Wallace, D. W. R., Tilbrook, B., Milllero, F. J., Peng, T.-H., Kozyr, A., Ono, T., and Rios, A. F.: The Oceanic Sink for Anthropogenic $\mathrm{CO}_{2}$, Science, 305, 367-371, 2004.

Sato, H., Itoh, A., and Kohyama, T.: SEIB-DGVM: A new dynamic global vegetation model using a spatially explicit individual-based approach, Ecol. Modell., 200, 279-307, doi:10.1016/j.ecolmodel.2006.09.006, 2007.

Seibel, B. A. and Walsh, P. J.: Potential impacts of CO2 injections on deep-sea biota, Science, 294, 319-320, 2001.

Semtner Jr., A. J.: A model for the thermodynamic growth of sea ice in numerical investigations of climate, J. Phys. Oceanogr., 6, 379-389, 1976.

Steinacher, M., Joos, F., Frölicher, T. L., Plattner, G.-K., and Doney, S. C.: Imminent ocean acidification in the Arctic projected with the NCAR global coupled carbon cycle-climate model, Biogeosciences, 6, 515-533, doi:10.5194/bg-6-515-2009, 2009.

Stroeve, J., Holland, M. M., Meier, W., Scambos, T., and Serreze, M.: Arctic sea ice decline: Faster than forecast, Geophys. Res. Lett., 34, L09501, doi:10.1029/2007GL029703, 2007.

Wang, M. and Overland, J. E.: A sea ice free summer Arctic within 30 years?, Geophys. Res. Lett., 36, L07502, doi:10.1029/2009GL037820, 2009.

Watanabe, S., Hajima, T., Sudo, K., Nagashima, T., Takemura, T., Okajima, H., Nozawa, T., Kawase, H., Abe, M., Yokohata, T., Ise, T., Sato, H., Kato, E., Takata, K., Emori, S., and Kawamiya, M.: MIROC-ESM 2010: model description and basic results of CMIP5-20c3m experiments, Geosci. Model Dev., 4, 845-872, doi:10.5194/gmd-4-845-2011, 2011.

Yamamoto-Kawai, M., McLaughlin, F. A., Carmack, E. C., Nishino S., and Shimada, K.: Aragonite Undersaturation in the Arctic Ocean: Effects of ocean acidification and sea ice melt, Science, 326, 1098-1100, doi:10.1126/science.1174190, 2009.

Yoshikawa, C., Kawamiya, M., Kato, T., Yamanaka, Y., and Matsuno, T.: Geographical distribution of the feedback between future climate change and the carbon cycle, J. Geophys. Res., 113, G03002, doi:10.1029/2007JG000570, 2008.

Zeebe, R. E., Zachos, J. C., Caldeira, K., and Tyrrell, T.: Carbon emissions and acidification, Science, 321, 51-52, 2008. 